\title{
The 1964 coup and dictatorship in opinion polls
}

\author{
Rodrigo Patto Sá Motta[1]
}

\begin{abstract}
This article analyzes opinion polls conducted by the Brazilian Institute of Public Opinion and Statistics (IBOPE) in the context of 1964, with the objective of assessing the support to the coup and to dictatorship. The data, mostly new, indicate a contrast between the support to João Goulart, registered before the coup, and after the success of the coup, which points out to the good acceptance of authoritarian measures, including political purges. The empirical data obtained from the polls are used to consider the sources of legitimation of dictatorship that especially mobilized anticommunist representations. The analysis of the records suggests that the support to the authoritarian regime was marked by instability and oscillated throughout the initial years.
\end{abstract}

Keywords: dictatorship; IBOPE; 1964 coup.

\section{O golpe de 1964 e a ditadura nas pesquisas de opinião}

\section{Resumo}

O artigo analisa pesquisas de opinião realizadas pelo Instituto Brasileiro de Opinião Pública e Estatística (IBOPE) no contexto de 1964, com o objetivo de avaliar o apoio ao golpe e à ditadura. Os dados, na maioria inéditos, apontam um contraste entre o apoio a João Goulart, registrado antes do golpe, e os números colhidos depois da vitória golpista, que indicam boa aceitação das medidas autoritárias, inclusive os expurgos políticos. O material empírico resultante das enquetes é utilizado para refletir sobre as fontes de legitimação da ditadura que mobilizaram, sobretudo, representações anticomunistas. A análise dos registros sugere que o apoio ao regime autoritário foi marcado pela instabilidade e oscilou no decorrer dos primeiros anos.

Palavras-chave: ditadura; IBOPE; golpe de 1964.

\section{El golpe de 1964 y la dictadura en los sondeos de opinión}

\section{Resumen}

El artículo analiza los sondeos de opinión realizados por el Instituto Brasileño de Opinión Pública y Estadística (IBOPE) en el contexto de 1964, con el objetivo de evaluar el apoyo al golpe y a la dictadura. Los datos, en su mayoría inéditos, señalan un contraste entre el apoyo a João Goulart, apuntado antes del golpe, y los números recogidos después de la victoria golpista, que indican la buena aceptación de medidas autoritarias, incluyendo purgas políticas. El material empírico resultante de los sondeos se utiliza para reflexionar sobre las fuentes de legitimidad de la dictadura, que movilizaron principalmente representantes anticomunistas. El análisis de los registros insinúa que el apoyo al régimen autoritario se caracterizó por la inestabilidad y fluctuó durante los primeros años.

Palabras clave: dictadura; IBOPE; el golpe de 1964.

\section{Le coup d'État de 1964 et la dictature dans les sondages d'opinion}

\section{Résumé}

L'article analyse les sondages d'opinion réalisés par l'Institut Brésilien de l'Opinion Publique et des Statistiques (IBOPE) dans le contexte de 1964, dans le but d'évaluer le soutien au coup d'État et à la dictature. Les données, inédites pour la plupart, indiquent un contraste entre le soutien à João Goulart, enregistré avant le coup d'État et les chiffres recueillis après la victoire illicite qui indiquent une bonne acceptation des mesures autoritaires, y compris les épurations politiques. Le matériel empirique originaire des enquêtes est utilisé pour réfléchir sur les sources de légitimation de la dictature qui ont notamment mobilisé les représentations anticommunistes. L' analyse des registres suggère que le soutien au régime autoritaire a été marqué par l'instabilité et a oscillé au cours des premières années.

Mots-clés: dictature; IBOPE; coup d'État de 1964. 
his article proposes to reflect upon a polemic and politically delicate subject, which is essential: the support from some segments of the Brazilian society to the 1964 coup and to the subsequent dictatorship. The text relates to the recent historiographic production, which contributed to (re)bringing the subject to light; however, it is mostly based on opinion polls conducted during that time, both before and immediately after the coup. These are interesting sources to assess the support to the authoritarian intervention, as well as to analyze the results of the efforts to legitimize the dictatorship.

The social support to dictatorship is a polemic matter in current historiography, which had partly been inspired by studies about European fascist states and the context of the Nazi occupation. With that in mind, simplistic representations about the recent dictatorship have been questioned, since they exaggerate the polarization between those who resisted to it and those who collaborated with it, as if only two poles could distinguish the opinions of the actors of the time. One of the problems with simplified representations is the tendency to hide the support of expressive social segments to the dictatorial regime, which spontaneously joined it, without being coerced to do so. ${ }^{1}$

In order to understand the dictatorship, it is not sufficient to study repressive policies and the resistant actions it caused. It is also necessary to explain why a part of the society supported the dictatorial regime and to analyze the strategies used by the State and its agents to be legitimate. Admitting the existence of support to dictatorship, and the fact that it was considered to be legitimate by some segments of the society, is a risky analytical operation because of the possibility that academic arguments can be manipulated in political disputes to control the representation of the recent past. However, a more adequate understanding about the meaning of dictatorship is worth the risk, also for political reasons, because a more accurate knowledge can help understand the authoritarian regime, differently from the statements of simplified representations, even though the latter are more comfortable.

Regardless of the positive contribution of new historiography, deeper studies and reflections are required in order to avoid simplified analyses in the opposite direction. In terms of historiography that critically faces the memory of the authoritarian regime, the risks to be avoided are the overestimation of support to dictatorship and the underestimation of actions of opposition and resistance.

\footnotetext{
'Among recent historians who have approached this interpretation, see especially: Daniel Aarão Reis Filho, Ditadura militar, esquerdas e sociedade, Rio de Janeiro, Zahar, 2000 and Ditadura e democracia no Brasil, Rio de Janeiro, Zahar, 2014; Denise Rollemberg, "Memória, opinião e cultura política: a OAB sob a ditadura", In: Daniel Aarão Reis Filho; Denis Roland (orgs.), Modernidades alternativas, Rio de Janeiro, FGV, 2008, p. 5796; Denise Rollemberg; Samantha Quadrat, "Introdução", In: A construção social dos regimes autoritários. Legitimidade, consenso e consentimento no século XX, Rio de Janeiro, Civilização Brasileira, 2010, p. 31-44. It is worth to mention the word by Daniel Aarão Reis Filho, which was a call to question the dominant memory and an invitation to further studies about the social support to dictatorship. I stated that recent historiography replaced the matter in debate because authors from the 1970 s and 1980 s began thinking about the support to the coup and the attempts to make dictatorship legitimate, among them, Lúcia Klein, Legitimidade e coação no Brasil pós-64, Rio de Janeiro, Forense Universitária, 1978; René Dreifuss, 1964: a conquista do Estado, 2. ed., Petrópolis, Vozes, 1981; and Maria Helena Moreira Alves, Estado e oposição no Brasil (1964-1984), 4. ed., Bauru, EDUSC, 2005 [1984].
} 
However, it is important to consider more adequate concepts to analyze the support to the coup and to dictatorship. Part of academic literature has suggested the application of the concept of consensus, which was used in the case of fascism to indicate the solid support accomplished by the regime of Benito Mussolini. However, there is a conflict regarding the use of consensus in the context of dictatorships, since the concept is mostly used in cases in which liberal-representative institutions are prevalent. It is difficult to use the expression in authoritarian regimes because there is no freedom to criticize governors and voices of opposition are repressed. According to this interpretation, the existence of a consensus would only be proved in contexts of freedom of expression, that is, it would have to be freely expressed. ${ }^{2}$

The fear of threats to the order was pivotal in the
political crisis of 1964, and was specially expressed
by the anticommunist imaginary

Besides the conceptual difficulties, there are other reasons to think that the assumption of a consensus in favor of dictatorship in Brazil is not the best analytical option. The results of opinion polls allow us to analyze the matter in other terms, as we will approach it. Besides debating about which concepts are adequate to express the reality involving the social support to the dictatorship, the biggest challenge is to understand why some groups accepted the authoritarian intervention as a legitimate political option, and also to measure and map the sections of society that were influenced by the favorable opinion regarding the coup and dictatorship. The information we analyze here proves the support to dictatorship and offers a numerical expression of this phenomenon. However, at the same time, it points out to ranges that must be considered in reflections involving the social support to the authoritarian regime. As we will demonstrate, a high proportion of citizens supported the coup and political purges; however, the establishment of a military dictatorship did not attract the same enthusiasm.

The data analyzed here were taken from surveys conducted by the Brazilian Institute of Public Opinion and Statistics (IBOPE) in the context of the 1964 coup. Some of these polls were used by social scientists and historians in the early 1990s, right after IBOPE donated its collection to Arquivo Edgard Leuenroth

\footnotetext{
2Some authors doubt the usefulness of the concept even for liberal-representative regimes, since the expression would make the dimension of fractures and dissensus get lost. For discussions about the consensus in fascist and authoritarian regimes, see the collection by Denise Rollemberg; Samantha Quadrat, A construção social dos regimes autoritários. Legitimidade, consenso e consentimento no século XX. Rio de Janeiro, Civilização Brasileira, 2010, especially the introduction of the organizers and the chapter by Patrizia Dogliani. In the case of Brazil, it is possible to say that elections periodically won by dictatorship leaders were a symptom of consensual support. However, there has never been a scenario of total freedom (cassations, prisons, electoral casuistry) and, still, the opposition obtained important victories in some electoral disputes, like in 1965 and 1974.
} 
(AEL). Part of the material was analyzed by recent historiography; ${ }^{3}$ however, most opinion polls are still unpublished.

Before beginning to analyze the polls, it is worth mentioning that they should be used carefully. On the one hand, because they can reveal only brief opinions of the respondents, whose answers can also be induced depending on how the questionnaires were elaborated. Besides, under certain circumstances, the interest of making political use of the results leads to manipulation and falsification. On the other hand, in the Brazilian case, it is important to take a better look at the opinion phenomena, since there are signs that the political opinion of the citizens is not always cared for solidity. The contrast between some polls shows conflicting results, which, in certain cases, suggest the occurrence of extreme opinion changes. Besides, the proportion of abstentions is always high, that is, people who prefer not to answer, or the ones who choose "I don't know" or "does not choose". It indicates there are many citizens whose political opinion is too superficial, showing they are uninformed or uninterested. Another limit is the fact that surveys were restricted to some cities, in general to São Paulo or Rio de Janeiro. In this case, no surveys were conducted in the entire country because these were rare at that time. The broader poll included the capital of São Paulo and two cities in the countryside, Araraquara and Avaí, probably to offer elements for comparison and project what would be the opinion in the whole State of São Paulo.

Despite the necessary observations and care, some considerations weakened the skepticism and led us to believe that these records can be used as sources of information. First, apparently these polls were not intended for publication, which reduces the interest in manipulating the citizens' opinions. The objective of people who financed these polls was probably to obtain data in order to plan political actions and assess the results of some advertisement campaigns. In some cases, due to the nature of the questions asked, one gets the impression they were requested by the military government to evaluate the society's opinion about its policies. There are no records indicating these polls being published at the time they were conducted; ${ }^{4}$ so, they would be unknown until recently, stored in the files. Finally, the fact that the polls were restricted to some cities does not reduce their representativeness, since they included the most important cities

\footnotetext{
${ }^{3}$ The donation of IBOPE to AEL took place in 1989. The first researcher to use the collection was Antônio Lavareda (A democracia nas urnas, Rio de Janeiro, Rio Fundo; IUPERJ, 1991). In recent publications dedicated to the coup and to dictatorship, historians Marcos Napolitano (1964: história do Regime Militar Brasileiro, São Paulo, Contexto, 2014) and Jorge Ferreira; Angela de Castro Gomes (1964: o golpe que derrubou um presidente, pôs fim ao regime democrático e instituiu a ditadura no Brasil, Rio de Janeiro, Civilização Brasileira, 2014) also used some polls from IBOPE.

${ }^{4}$ According to Antônio Lavareda, op cit., p. 123, who investigated the polls from IBOPE from the 1950 s and the 1960s, newspapers had little interest in opinion surveys, and the main clients of the institute were politicians and businesspersons. It was not possible to find information about who ordered the polls, or that they were published at the time. In some polls, the term "IBOPE FECIT" is recorded, which can only mean "IBOPE did it", in a translation from the Latin term fecit. All of the IBOPE surveys mentioned in this text are filed in AEL. In the documents donated by IBOPE, there are different types of polls, and not only political ones: there are surveys on consumption, audience of TV and radio shows, publicity and advertisement, reading habits, among others. Other comments and information about the techniques and methodologies of the polls will be presented in the following footnotes.
} 
in the country that were able to influence broader issues, and the comparison between the results in these big cities reveals an agreement between opinions.

Another favorable argument to skepticism was presented by colleagues during events when these surveys were presented. They questioned the validity of polls conducted after the coup, suggesting that the respondents would avoid telling the truth for fear of repression. The argument is little convincing for two reasons: interviews were anonymous, so it would be difficult for respondents to feel threatened; and, most importantly, some polls revealed results that were contrary to the interests of dictatorship, which shows the option to give negative answers to the State in case the respondents wished to do so.

The reports from IBOPE offer several interesting analytical possibilities, since some surveys were stratified by income levels and gender. ${ }^{5}$ Because of the difficulty to explore all possibilities in this article, we chose to work only on the main results. The main objective was to measure the proportion of the people who supported the coup and to assess their motivation to do so. Another objective was to speculate about whether or not military men would have the support for a "classic dictatorship", that is, one that would annul all liberal institutions and establish a more explicit authoritarian option.

\section{Polls prior to the coup}

One of the major challenges in the analysis of the polls is to understand the oscillations - and the contrast - between opinions expressing the support to João Goulart (Jango) and those agreeing with his deposition. Polls conducted a few days before the 1964 coup show significant support to Goulart. However, other polls conducted by IBOPE about two months later reveal remarkable support to the coup. How is it possible to understand this paradox?

First, let us look at polls that indicate the popularity of Goulart and the support to the project of "fundamental reforms". According to these data, Jango was seen positively by expressive social segments and was very popular. Fundamental reforms, especially the Agrarian Reform, attracted more support from the society (with one exception we will discuss later), and these reforms were more popular than Goulart. Here are some data of one of the most complete studies found in the collection, which was conducted in the cities of São Paulo, Araraquara, and Avaí from March 20 to March 30, 1964. Let us start with the evaluation of the Goulart administration (Table 1).

Similar surveys were conducted in other Brazilian cities, with results that were either more positive or more negative for Goulart. However, this survey is interesting because it allows us to compare the opinions manifested in a big

${ }^{5}$ Even though there is no space for further analyses, some impressions were taken by reading the material: higher level of abstention among poorer classes and more acceptance to conservative arguments (in general, anticommunists) among richer people and women. More about that is given afterwards. Still on the used methodology, IBOPE registered that the representativeness of the sample was based on gender-based stratification, as well as socioeconomic profiles and geographic distribution. The samples included around 500 interviewees in each city. The size of the sample and distribution criteria are close to the ones used nowadays. 
Table 1. Poll from the Brazilian Institute of Public Opinion and Statistics (IBOPE) conducted between March 20 and March 30, 1964, based on 950 interviews

\begin{tabular}{lcccccc}
$\begin{array}{l}\text { How do you see the administration } \\
\text { of João Goulart so far? }\end{array}$ & Great & Good & Average & Bad & $\begin{array}{c}\text { Very } \\
\text { bad }\end{array}$ & $\begin{array}{c}\text { Do not } \\
\text { know }\end{array}$ \\
\hline São Paulo & $13 \%$ & $29 \%$ & $30 \%$ & $7 \%$ & $12 \%$ & $9 \%$ \\
\hline Araraquara & $15 \%$ & $24 \%$ & $23 \%$ & $10 \%$ & $11 \%$ & $17 \%$ \\
\hline Avaí & $18 \%$ & $37 \%$ & $19 \%$ & $5 \%$ & $5 \%$ & $16 \%$ \\
\hline Source: Arquivo Edgard Leuenroth. & & & & & &
\end{tabular}

city with two countryside cities. The result shows little variation between the opinions manifested in each city, except for a higher rate of non-respondents in the smaller cities and more popularity for Goulart in Avaí. Considering just São Paulo, the Jango administration was seen as great/good by $42 \%$, average by $30 \%$, and bad/very bad by only $19 \%$. Data show that, before his deposition, the president had a relatively positive image among residents of São Paulo.

An important aspect is that the survey tried to verify the repercussion of the rally held on March 13, 1964, in Guanabara (Rio de Janeiro), which marked the more intense commitment toward the realization of reforms. However, IBOPE did not ask questions related to the event of March 19, in São Paulo, the fact known as March of the Family with God for Freedom, which represented a major liberal-conservative mobilization in response to the March 13 rally. Maybe the poll was already ready and it was not possible to incorporate questions related with the new event; anyway, the respondents were already under the impact of the March.

Data show that the support to Goulart remained high, and that most people preferred the reforms. However, the survey also indicated a remarkable repudiation of communism, and also registered the sensation that the "red danger" was growing, which was exactly the main theme of the right-wing campaign. We will get back to that, but first, let us analyze the opinion about the reforms.

Many opinion polls conducted at that time showed a strong support to the fundamental reforms, and these data have been known for a long time. ${ }^{6}$ The polls show that the total repudiation of reforms, which could be called anti-reformism, was weak in the public opinion. ${ }^{7}$ In the survey conducted in the three cities of São Paulo, the subject was very much explored (Table 2).

Without considering the small differences found in the answers of respondents from the three cities, a high level of support to the demand for reforms can be seen. The percentage of people who found them to be unnecessary was very little, and the favorable opinion regarding the urgency of reforms was expressed by approximately $40 \%$. The results of other surveys are in agreement with these

\footnotetext{
${ }^{6}$ Specially data on the agrarian reform. Cf. Antônio Lavareda, A democracia nas urnas, Rio de Janeiro: Rio Fundo/IUPERJ, 1991, p. 157.

${ }^{7}$ Naturally, public opinion is not seen as being still and singular; on the contrary, it would be prudent to talk about opinions to consider such a complex phenomenon. About that, see Jean-Jacques Becker, "A opinião pública”, In: René Rémond (org.), Por uma história política, 2. ed., Rio de Janeiro, FGV, 2003, p. 185-211.
} 
Table 2. Poll from the Brazilian Institute of Public Opinion and Statistics (IBOPE) conducted between March 20 and March 30, 1964, based on 950 interviews

\begin{tabular}{lcccc}
$\begin{array}{l}\text { With regard to the } \\
\text { fundamental reforms idealized } \\
\text { by the president João Goulart, } \\
\text { do you think they are: }\end{array}$ & $\begin{array}{r}\text { Absolutely } \\
\text { necessary, } \\
\text { with urgency }\end{array}$ & $\begin{array}{c}\text { Necessary, } \\
\text { however, with } \\
\text { moderation, } \\
\text { without hurrying }\end{array}$ & $\begin{array}{c}\text { Not } \\
\text { necessary }\end{array}$ & $\begin{array}{c}\text { Do not } \\
\text { know }\end{array}$ \\
São Paulo & $40 \%$ & $39 \%$ & $7 \%$ & $14 \%$ \\
\hline Araraquara & $39 \%$ & $24 \%$ & $7 \%$ & $30 \%$ \\
\hline Avaí & $52 \%$ & $17 \%$ & $6 \%$ & $25 \%$ \\
\hline
\end{tabular}

Source: Arquivo Edgard Leuenroth.

data, especially the ones involving the Agrarian Reform, which show an average of $70 \%$ of support in the polls conducted in several Brazilian cities. ${ }^{8}$

However, one of the intended political reforms did not have the same support and divided the opinions: the proposal to extend the right to vote to illiterate people. In the same poll, respondents of São Paulo, Araraquara, and Avaí were asked whether or not they were in favor of this measure, which was supported by left-wing parties. The result was much different in comparison to the opinions about other reforms, because $49 \%$ of citizens from São Paulo disagreed with the right to vote extended to illiterate people, and $46 \%$ were in favor of the proposal. Similar polls in other regions of the country showed the same (or higher) level of rejection regarding the right to vote to illiterate people: in Minas Gerais, in September 1963, 76\% respondents answered "no" to the proposal, and only $23 \%$ supported it; in Guanabara, in October 1963, 55\% of the voters were against the right to vote for illiterate people, and $43 \%$ were in favor of it.

\section{Many citizens supported the reforms and had a good impression of the Goulart government; however, they repudiated more radical left-wing alternatives}

By analyzing these data, one of the possible conclusions drawn is that the opinion was mostly reformist when changes would affect the interest of a few people, like in the case of land distribution, since this would only affect important landowners. However, in the case of conceiving the right to vote to illiterate people, the proposal affected broader interests and aroused fears, since the inclusion of a huge mass of poor and excluded people in the electoral system could change the political scale and favor the left wing, or the "demagogues", as expressed by the opinion of the right wing groups. An interesting fact is that another point of the political reform, which is the right of subalterns from the

${ }^{8} \mathrm{Cf}$. Jorge Ferreira; Angela de Castro Gomes, 1964: o golpe que derrubou um presidente, pôs fim ao regime democrático e instituiu a ditadura no Brasil, Rio de Janeiro, Civilização Brasileira, 2014, p. 295. 
Armed Forces to vote and be voted, attracted the support from most respondents. Even though it was a politically explosive matter, since it unpleased the right wing and divided the opinions of the military men, the election of subalterns did not affect most of the public opinion. ${ }^{9}$ However, the vote for the illiterate people did. This contrast reveals that many people would accept moderate social changes, however, at the same time, most of them feared the possibility of more acute transformations.

The fear of threats to the order was pivotal in the political crisis of 1964 and was especially expressed by the anticommunist imaginary. ${ }^{10}$ Anticommunist movements had been part of the State's repertoire and right wing groups since the beginning of the century; however, from 1961 to 1964, they reached high peaks as a result of the combination of internal (increment in claims and social protests) and external factors (the Cold War, revolutions in the Third World). When Goulart was deposed in 1964, the anticommunist representations played a key role and the polls allow us to understand it better. Let us see some examples in Tables 3 and 4 .

The study measured the opinion of inhabitants of Rio de Janeiro about one of the events that polarized the left and the right wings in 1963. It was the attempt to conduct the Congress of Solidarity with Cuba in Guanabara, which was naturally organized by left wing groups. The conduction of the event in Guanabara was forbidden by the governor and anticommunist leader Carlos Lacerda, thus generating a national conflict. The results of the poll show that most (63\%) people from Rio de Janeiro supported the governor's act, and that a little lower percentage, however still high (49\%), agreed to the statement that the event would threaten the democratic institutions and national security.

Other polls show the increase of the anticommunist sensitivity. In February 1964, in an analysis that explored several political themes, IBOPE asked the following question to the respondents from São Paulo: "do you think communism is gaining strength or fading away"? The result was that $54 \%$ of participants answered "gaining strength", and $16 \%$, "fading away", whereas $28 \%$ of them did not have an opinion. The most interesting part was the following question, replied only by the $54 \%$ who answered that the communism was gaining strength. This question was probably planned to measure the anticommunist opinion and to distinguish the percentage of people leaning to the left. That second question was whether communism represented danger or not, and $81 \%$ said "yes", against $13 \%$ who answered "no". With simple math, the result is that, just before the coup, $44 \%$ of the citizens from São Paulo ( $81 \%$ of $54 \%$ ) saw communism as a danger.

Going back to the poll conducted in March 1964 in the cities of São Paulo, Araraquara, and Avaí, the result demonstrated that $42 \%$ of the opinions were in favor of the Goulart administration, and there was a strong support to fundamental reforms; we also found important records about repudiation of the left wing. For instance, one of the questions addressed the legalization

\footnotetext{
In another poll in Guanabara (June 1964), in which most interviewees was against granting the right to vote to illiterate people, $76 \%$ were in favor of votes for sergeants.

${ }^{10} \mathrm{Cf}$. Rodrigo Patto Sá Motta, Em guarda contra o perigo vermelho: o anticomunismo no Brasil (1917-1964), São Paulo, Perspectiva; FAPESP, 2002
} 
Table 3. Poll from the Brazilian Institute of Public Opinion and Statistics (IBOPE) in Guanabara (Rio de Janeiro) conducted between March 29 and March 31, 1963, based on 511 interviews

\begin{tabular}{lccc}
$\begin{array}{l}\text { Did governor Lacerda do well by forbidding } \\
\text { the Congress of solidarity to Cuba? }\end{array}$ & Yes & No & $\begin{array}{c}\text { Do not know/ } \\
\text { did not say }\end{array}$ \\
\hline
\end{tabular}

Source: Arquivo Edgard Leuenroth.

Table 4. Poll from the Brazilian Institute of Public Opinion and Statistics (IBOPE) in Guanabara (Rio de Janeiro) conducted between March 29 and March 31, 1963, based on 511 interviews The performance of this Congress represents a threat to National Security and democratic institutions?

Yes

$49 \%$
No

$25 \%$
Do not know/ did not say

Source: Arquivo Edgard Leuenroth.

of the Brazilian Communist Party (PCB), which was being considered by the Goulart administration. Most right-wing forces were opposed to the proposal, even though some leaders preferred to legalize the party so they could have more control over the activities. The survey revealed that $80 \%$ of the respondents from São Paulo were opposed to legalizing PCB, and only 13 were in favor of it. Even though the data were inconclusive about whether or not all of those who were opposed to PCB had solid anticommunist values, they certainly point to that direction. It is worth reproducing the result of another question asked by IBOPE to measure the anticommunist opinion (Table 5).

It is worth to mention - and the comment is also valid for the previously demonstrated polls - that the construction of the question reveals the connection with the anticommunist imaginary, since the use of the term "danger" already indicates condemnation. Therefore, the poll may influence the political opinion of the interviewees. However, there was the possibility to deny the anticommunist speech by choosing the third response ("it is not a danger").

The results in the three cities were very converging, except for the higher number of abstentions in the countryside. Considering the data from São Paulo, $32 \%$ of the participants answered that the danger was immediate and $36 \%$ claimed the danger would be in the future; therefore, $68 \%$ of the participants chose to refer to communism as being dangerous. In the other two cities, this number was also higher than $60 \%$. Data show the significant impact of anticommunist campaigns, as well as the increasing concerns about the presence of communism in the public scenario if we compare it with the results of the poll conducted in February 1964. Also, the surveys suggest potential support of the expressive social sectors to the anti-left policies. We will demonstrate in the next section that, after the coup, the number of citizens supporting the purge to the leftwing parties was high. 
Table 5. Poll from the Brazilian Institute of Public Opinion and Statistics (IBOPE) conducted between March 20 and March 30, 1964, based on 950 interviews

\begin{tabular}{lcccc}
$\begin{array}{l}\text { Do you think communism, } \\
\text { for Brazil, represents: }\end{array}$ & $\begin{array}{c}\text { Immediate } \\
\text { danger }\end{array}$ & $\begin{array}{c}\text { A danger in } \\
\text { the future }\end{array}$ & $\begin{array}{c}\text { It is not a } \\
\text { danger }\end{array}$ & $\begin{array}{c}\text { Does not } \\
\text { know it }\end{array}$ \\
\hline São Paulo & $32 \%$ & $36 \%$ & $19 \%$ & $13 \%$ \\
Araraquara & $37 \%$ & $26 \%$ & $15 \%$ & $22 \%$ \\
Avaí & $37 \%$ & $24 \%$ & $9 \%$ & $30 \%$ \\
\hline
\end{tabular}

Source: Arquivo Edgard Leuenroth.

It is important to mention that one must not confuse anticommunist sensitivity and the fear of threats against the social order with the evaluations about the Goulart administration. The poll conducted in the three cities of São Paulo, besides the surveys conducted in other Brazilian cities, show that the sympathy for reforms and for Goulart existed side by side with anticommunist values. In other words, many citizens supported the reforms and had a good impression about the Goulart administration; however, they repudiated more radical left-wing alternatives. Besides, only a few people directly associated Goulart to the "danger of communism", which can be seen in the answers of another question used in the same poll (Table 6).

\section{The polls conducted after May 1964 indicate a change in opinion, and most people were in agreement with Goulart's deposition and favorable to political purges}

The question refers to the measures announced by Goulart in the rally of Central do Brasil, which marked the impulse of the government toward a more incisive reformist policy. Conservative leaderships saw the event as a left-wing impulse of the president and responded with the March with God, in São Paulo, and the increase in talks of coup in several parts of the country. However, the poll conducted by IBOPE between March 20 and March 30 shows a high confidence in the reformist policies of the president, with more than $50 \%$ favorable answers (55\% in the capital of São Paulo). Opinions that were opposed to Goulart were restricted to $26 \%$ in São Paulo, and only $16 \%$ associated the rally of Central do Brasil with a supposedly communist attack.

A few days before the coup that would depose Goulart, the IBOPE survey showed that about half of the voters from São Paulo trusted the president's intentions, while just one quarter was sensitive to the opposite speech. However, it is worth mentioning that the potential support for anticommunist campaigns was huge, and in case the opposition forces could "attach" Goulart's image to the "communist danger", the political effects would be remarkable. 
Table 6. Poll from the Brazilian Institute of Public Opinion and Statistics (IBOPE) conducted between March 20 and March 30, 1964, based on 950 interviews

\begin{tabular}{lcccc}
$\begin{array}{l}\text { Which of these ways } \\
\text { of thinking is more } \\
\text { in accordance with } \\
\text { your opinion about } \\
\text { the last measures of } \\
\text { president? }\end{array}$ & $\begin{array}{c}\text { These are } \\
\text { demagogic } \\
\text { measures, } \\
\text { which aim at } \\
\text { increasing the } \\
\text { prestige of Mr. } \\
\text { Goulart and PTB }\end{array}$ & $\begin{array}{c}\text { These } \\
\text { are real } \\
\text { interesting } \\
\text { measures for } \\
\text { the people } \\
\text { and the } \\
\text { country }\end{array}$ & $\begin{array}{c}\text { These measures } \\
\text { try to create } \\
\text { conditions } \\
\text { for the } \\
\text { establishment } \\
\text { of a communist } \\
\text { regime in Brazil }\end{array}$ & $\begin{array}{c}\text { Do not } \\
\text { know }\end{array}$ \\
\hline São Paulo & $10 \%$ & $55 \%$ & $16 \%$ & $19 \%$ \\
\hline Araraquara & $10 \%$ & $47 \%$ & $16 \%$ & $27 \%$ \\
Avaí & $8 \%$ & $53 \%$ & $8 \%$ & $31 \%$ \\
\hline
\end{tabular}

Source: Arquivo Edgard Leuenroth.

\section{Opinion polls after the coup}

In IBOPE's collection, the first poll after the coup, which was carried out shortly after the event, was conducted between May 12 and May 22, 1964, in the city of São Paulo. The results of this survey - as well as that of others that will be shown ahead - implicate a major analytical challenge, since they reveal a paradox in the comparison with the poll conducted in late March 1964. In that survey, respondents seemed to be relatively confident about the Goulart administration, at least in terms of proposals of fundamental reforms. However, polls conducted after May 1964 indicate a change in opinion, and most people were in agreement with Goulart's deposition and favorable to political purges, especially when targets were from the left groups (Tables 7 and 8).

According to the presented numbers, approximately one and a half month after the coup, most of the voters from São Paulo approved the new political situation and had positive expectations for the future. The most remarkable thing is that $54 \%$ of the participants from São Paulo considered Goulart's deposition to be beneficial, but two month earlier, at the end of March, $42 \%$ thought his government was good or great, and only $19 \%$ considered it to be bad or very bad (30\% assessed him as average). How is it possible to explain this apparent change in opinion in such a short period? Different opinions among voters are common and, as we will see, the evaluation of the first military government changed a lot between 1964 and 1965. What calls the attention is how fast this process occurred in this case.

First, it is important to consider that the $54 \%$ of people who approved Goulart's deposition represent a slight majority, little more than half of the voters from São Paulo. This means that the number of those who changed opinion may not have been as high. Hypothetically speaking, we could assume that the $30 \%$ of those who thought Jango was average joined the opinion of the $19 \%$ who made a negative evaluation, and that part of those who sympathized with the government changed opinion at the time of the coup. Another hypothesis to consider is that the polls 
Table 7. Poll from the Brazilian Institute of Public Opinion and Statistics (IBOPE) conducted between May 12 and May 22, 1964, in São Paulo, based on 500 interviews

\begin{tabular}{lccc}
$\begin{array}{l}\text { In your opinion, Goulart's deposition was a } \\
\text { beneficial or a bad measure for the country? }\end{array}$ & $\begin{array}{c}\text { Beneficial } \\
54 \%\end{array}$ & $\begin{array}{c}\text { Bad } \\
20 \%\end{array}$ & $\begin{array}{c}\text { Do not } \\
\text { know }\end{array}$ \\
\hline
\end{tabular}

Source: Arquivo Edgard Leuenroth.

Table 8. Poll from the Brazilian Institute of Public Opinion and Statistics (IBOPE) conducted between May 12 and May 22, 1964, in São Paulo, based on 500 interviews

\begin{tabular}{lcccc}
$\begin{array}{l}\text { In your opinion, the situation of Brazil } \\
\text { now tends to improve or get worse? }\end{array}$ & $\begin{array}{c}\text { Improve } \\
\text { I0\% }\end{array}$ & $\begin{array}{c}\text { Get } \\
\text { worse }\end{array}$ & $\begin{array}{c}\text { Stay the } \\
\text { same }\end{array}$ & $\begin{array}{c}\text { Do not } \\
\text { know }\end{array}$ \\
\hline
\end{tabular}

Source: Arquivo Edgard Leuenroth.

conducted at the end of March 1964 may not have measured the impact of the crisis, especially the episode of the sailors from Guanabara, on March 25 and 26, which had a strong effect on the destabilization of the Goulart government.

Besides, it is important to consider the influence of a successful coup on the opinion of the citizens. The winners launched a discursive campaign to convince that their action was necessary in the interest of the majority of people. In this sense, the media that was mostly committed to the coup - like the influent O Globo and O Estado de S. Paulo — worked hard to defend the "March 31st" and to criticize the deposed government and its left-wing allies. It is not about overrating the influence of the media concerning the support to the military regime, after all, the values that justified the coup were already part of the political scenario; besides, some press vehicles that supported Goulart's deposition soon departed from the pro-coup opinion and began to criticize repressive actions of the new government. Still, speeches that were favorable to the coup were prevalent in the media in the first weeks, and probably contributed to change the opinion on part of the citizens.

Another question that was present in the same question (May 1964) enables us to assess the influence of pro-coup speeches and confirms the high percentage of people from São Paulo who were favorable to Goulart's deposition (Table 9).

The options offered to the respondents condensed the main arguments in the political debate, and the second question, which only attracted $17 \%$ of the responses, represented the dominant left view. The first and the third options corresponded to the pro-coup visions, and together they accounted for $55 \%$ of the responses; this percentage was almost identical to the $54 \%$ that considered Goulart's deposition to be beneficial. Significantly, the option that attracted more responses (34\%) associated the pro-coup motivation with the fight against "communism", that is, Goulart would have been deposed because his government could lead the country to communism. This result is in contrast with the $16 \%$ respondents who, in March 1964, answered that the reformist plan of Goulart had communist intentions. It is not necessary to repeat the analysis conducted a little 
Table 9. Poll from the Brazilian Institute of Public Opinion and Statistics (IBOPE) conducted between May 12 and May 22, 1964, in São Paulo, based on 500 interviews

\begin{tabular}{lcccc}
$\begin{array}{l}\text { To which of } \\
\text { these reasons } \\
\text { do you attribute } \\
\text { the deposition } \\
\text { of president } \\
\text { João Goulart? }\end{array}$ & $\begin{array}{c}\text { leading } \\
\text { Brazil } \\
\text { toward a } \\
\text { communist } \\
\text { regime }\end{array}$ & $\begin{array}{c}\text { He was taking popular } \\
\text { measures that were } \\
\text { opposed to strong } \\
\text { interests from economic } \\
\text { and financial groups, } \\
\text { both national and } \\
\text { foreign }\end{array}$ & $\begin{array}{c}\text { He intended } \\
\text { to shut down } \\
\text { the Congress } \\
\text { (Chamber } \\
\text { and Senate) } \\
\text { to become a } \\
\text { dictator }\end{array}$ & $\begin{array}{l}\text { Do not } \\
\text { know }\end{array}$ \\
\hline
\end{tabular}

Source: Arquivo Edgard Leuenroth.

while ago about the possibility of changing opinions. But it is worth mentioning that the anticommunist fear had always been present in the scenario, and that the opinions of May 1964 indicate that the image of Goulart was effectively associated with the "red danger", and that justified the coup for many people.

It is interesting to analyze the data in this research considering the social stratification of the respondents, who were divided by IBOPE into classes A-B (rich and middle), C (under) and D (lower underclass). Data confirm something that contemporary observers indicated at the time: the higher classes welcomed the coup with more enthusiasm. In classes A-B, the number of abstentions was lower, and responses that agreed with the pro-coup opinion increased to $67 \%$, while $42 \%$ believed that Goulart would be taking Brazil toward communism, and $25 \%$ indicated the supposed intention of shutting down the Congress. The results from the class $\mathrm{C}$ were similar to the general results, however, in the class $\mathrm{D}$, the numbers show that it was the least excited social segment with the new political situation. In the poorest social stratum, the number of abstentions was higher, because it reached $42 \%$. However, in class D, the proportion of those associating Goulart's deposition to initiatives of popular interest was higher $(21 \%)$, and the number of those who believed in the argument of communist danger was lower (19\%). Nonetheless, even in class D, the acceptance of procoup speeches was prevalent, since the sum of options 1 and 3 accounted for $37 \%$ of the preferences (the $19 \%$ we already mentioned plus the $18 \%$ who chose the argument that Goulart would shut down the Congress).

To conclude the analysis of the results of the poll conducted between May 12 and May 22, 1964, in São Paulo, it is worth to mention some sections indicating the support to some actions of the dictatorship, including the purges. In the records, it is possible to observe with consternation that most respondents agreed with the political punishments, especially if the targets were the left groups. IBOPE asked if cassation of the mandates of communist politicians had been a correct initiative. In reply to the question, $74 \%$ said "yes" and only $12 \%$ criticized the purge. The next question was about the imprisonment of union leaders connected to communists. The replies from respondents from São Paulo were mostly favorable ( $72 \%$ ), and only $12 \%$ were opposed it. 
Another survey conducted in São Paulo some days later, in the last week of May, again explored the support to political repression. This time, residents of São Paulo were asked about whether they were in favor of cassations in general, certainly to make a distinction in comparison to the previous poll, which only questioned about the purge of communists. The support to "cassations in general" was less common than that to the purge of communists; however, it was still high: $57 \%$ in favor, $15 \%$ against, and $28 \%$ abstentions. There is a significant point: most people supported the purges; however, when the purge involved the communists, this proportion was even higher.

\section{Winners launched a discursive campaign \\ to convince that their action was necessary in the interest of the majority of people}

Results from other studies confirm the good response from voters regarding the government that took over after the coup, including surveys conducted in Guanabara. The most striking factor is the revelation of the support from people of Rio de Janeiro to the initial purge policies of dictatorship, similarly to what was observed in São Paulo. In the last week of May 1964, IBOPE approached 511 people in Guanabara and asked questions to measure the opinion about the new regime. One of them was: "by the measures adopted in the economicfinancial field, what do you think of the Castelo Branco administration"? The responses were answered as follows: $51 \%$ said it was good or great, $6 \%$ thought it was bad or very bad, and $21 \%$ thought it was average. To assess the opinion on purges, they were questioned about the "cassation of mandates and suspension of political rights in general". The favorable response was from $56 \%$, while only $21 \%$ of the respondents claimed to be against the cassations. ${ }^{11}$

One of the questions included in this study, and that was also present in a survey conducted in São Paulo, explored the opinion on the motivation of purges (Table 10).

It is possible to observe the adherence of most people to speeches that were favorable to the coup, by accepting the argument that cassations aimed at the enemies pointed out by coup defenders: communists, subversives, and corrupts. The last option in the survey, which attracted $28 \%$ responses, probably aimed at assisting the respondents who did not support the purges, since it explained the punishments for the motive of "political persecutions". It was a suggestion that the purge process was illegitimate, not in agreement with the arguments presented by the government, that is, it would be about political persecutions 
Table 10. Poll from the Brazilian Institute of Public Opinion and Statistics (IBOPE) conducted in the last week of May 1964, in Guanabara, based on 511 interviews

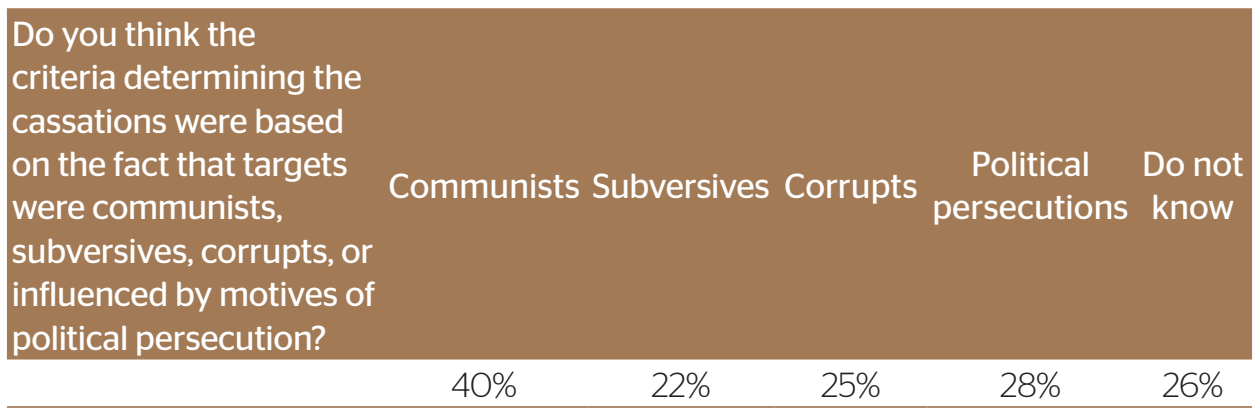

Source: Arquivo Edgard Leuenroth.

Note: The researchers included a methodological note to explain why the sum of responses was more than $100 \%$ - because interviewees could choose more than one option.

promoted by objectives other than the hunt for communists, subversives, and corrupts. The results of this poll show the prominence of the anticommunist theme, even though IBOPE also provided the answer "subversives" - a more vague definition for the left-wing groups. Therefore, anticommunism also sensitized the privileged social classes: in classes A-B, the option "communists" had $50 \%$ of the preferences, while in the class D only $25 \%$ thought the motivation for punishments was to reach the communists.

In São Paulo, the same question was used in a poll conducted in the last week of May, and had similar answers to those of Rio: the option "communists" had 27\%; the option "subversives" had 14\%; the option "corrupts" had $16 \%$, while "political persecutions" was indicated by $19 \%$ respondents. In São Paulo, the anticommunist arguments also sensitized classes A-B more intensively, in which the option "communists" was chosen by $40 \%$ (and only by $16 \%$ in class D).

There is another survey that reveals the adherence to purge policies of dictatorship and the sympathy shown to the Castelo Branco administration in the beginning (which was pretty ephemeral, as we will see). The poll was conducted in Guanabara between June 24 and June 29, 1964, and one of the questions, which was not innocent, was: "if Castelo Branco makes a good administration, would you accept him to go on with his government, even without elections?" The plan of extending the general's mandate was already being negotiated in the corridors of power, and the poll was probably conducted to analyze how it would be received by public opinion. The answer probably made the defenders of the idea excited; after all, it was approved by the Congress in the second half of July. In that poll conducted at the end of June $1964,62 \%$ of respondents in Rio de Janeiro said they would accept the fact that Castelo Branco would still govern after the end of the "legal" mandate ${ }^{12}$ against $28 \%$ who were opposed and $10 \%$ who abstained.

\footnotetext{
${ }^{12}$ After taking over the presidency after the coup, by the indirect election in the Congress, the dominant idea was that Castelo Branco must conclude the constitutional mandate of Goulart. The mandate, which would end on January 31, 1966, was extended until March 15, 1967.
} 
The same poll used a question to assess the opinion of the voters with regard to the demand for amnesty for people persecuted for political reasons. The result shows that the opinion in favor of purges was still strong (Table 11).

Once again, the researchers decided to test the voters, specifically with regard to communists, distinguishing them from other politicians with the revoked mandate. The result shows the support to repressive dictatorial policies, since most were against a general amnesty (for the other politicians with the revoked mandate, that is, the ones who were not communists): $44 \%$ against and $36 \%$ in favor of forgiveness. The support to anticommunist purge was considerably higher, since only $14 \%$ considered the amnesty for communists to be a good measure, while $63 \%$ thought it was a bad idea to revoke their punishment.

So, the polls show the support of public opinion for policies of dictatorial purge, especially when they affected left-wing activists, and also revealed the good acceptance of the Castelo Branco administration in the first months. However, it was not all rosy for the military and the civil allies who took over in 1964. Polls show that the goodwill in relation to the new governors could be ephemeral, since in 1965 the "opinion" was impatient and made a negative evaluation of the Castelo Branco administration. Besides, even in surveys conducted right after the coup, the answers to some questions show that the support to authoritarian projects had limits. We can see that in Table 12.

The polls were conducted separately in both cities; however, in the same week with the same questions. They are grouped here for the ease of comparison. It is interesting how the results converge in both big cities, and that was also true for polls that were previously analyzed. The political significance that can be assessed from the poll is important. Many people supported the coup and political purges, demonstrating to accept the attacks against the Constitution and the disrespect for fundamental rights. However, most of them preferred to maintain the right to choose the governors directly, which implied a limit to accepting a classic dictatorship.

In that sense, the surveys conducted in Guanabara from June 24 to June 29,1964 , presented a significant data. In this survey, as mentioned before, the opinion of people from Rio de Janeiro was very favorable to the first military government, since most of them refused the amnesty and gave a favorable response to the proposal of extending the mandate of Castelo Branco.

However, when asked if, at first, the next president should be a civilian or a military man, 59\% respondents said that they would prefer Castelo Branco's successor to be a civilian, and only $16 \%$ were favorable to a military successor (there were $25 \%$ of abstentions).

Data allow the following interpretation: even if the coup and the purges had been accepted by most, it did not imply the same support to the establishment of a dictatorship. In other words, there may have been support to authoritarian actions, but not necessarily the support from most of the society to implement a military dictatorship. The polls suggest that the social support to a longlasting authoritarian project was unstable, and that it would not be easy to gain legitimacy and political stability for a dictatorship. 
Table 11. Poll from the Brazilian Institute of Public Opinion and Statistics (IBOPE) conducted between June 24 and June 29, 1964, in Guanabara, based on 500 interviews

\begin{tabular}{lccc}
$\begin{array}{l}\text { Would you consider the fact of the current } \\
\text { government establishing amnesty before the } \\
\text { elections of } 1965 \text { to be a good or a bad measure? }\end{array}$ & $\begin{array}{c}\text { A good } \\
\text { measure }\end{array}$ & $\begin{array}{c}\text { A bad } \\
\text { measure }\end{array}$ & $\begin{array}{c}\text { Did not } \\
\text { choose any }\end{array}$ \\
\hline For communists & $14 \%$ & $63 \%$ & $23 \%$ \\
\hline For others with revoked mandates & $36 \%$ & $44 \%$ & $20 \%$
\end{tabular}

Source: Arquivo Edgard Leuenroth.

Table 12. Polls from the Brazilian Institute of Public Opinion and Statistics (IBOPE) conducted in the last week of May 1964, in Guanabara (511 interviewees) and in São Paulo (519 interviewees)

\begin{tabular}{lccc}
$\begin{array}{l}\text { In your opinion, which is the best way to elect } \\
\text { the President of the Republic? }\end{array}$ & $\begin{array}{c}\text { Direct } \\
\text { election }\end{array}$ & $\begin{array}{c}\text { Indirect } \\
\text { election }\end{array}$ & $\begin{array}{c}\text { Do not } \\
\text { know }\end{array}$ \\
\hline Guanabara & $80 \%$ & $11 \%$ & $9 \%$ \\
São Paulo & $77 \%$ & $12 \%$ & $11 \%$
\end{tabular}

Source: Arquivo Edgard Leuenroth.

The challenges faced by the dictatorship leaders appeared more serious a few months later, in 1965, in a poll that shows the drastic fall in the popularity of the first military government among voters in Guanabara. In the poll conducted in the last week of May 1964, 51\% of the people from Rio de Janeiro rated the Castelo Branco administration as being great or good (considering the economic policy), against only $6 \%$ who answered "bad" or "very bad", and $21 \%$ who thought it was average. However, the survey conducted from February 5 to February 13 1965 showed an important change in the political expectations of the residents of Rio de Janeiro. The positive expectation and the optimism that was initially shown for dictatorship had died down, as we can see in Tables 13 and 14 .

The result confirms versions about the unpopularity of the Castelo Branco administration at the end of his mandate, and that would have led the second military president, Costa e Silva, to elaborate strategies to restore the prestige of the authoritarian regime. ${ }^{13}$ In the first question, most answers (73\%) pointed out to the worse economic situation in the comparison between the first year of the military government (1964) and the last year of Goulart (1963), which showed that the recessive policy used by the new administrators caused damage. ${ }^{14}$ The following question showed a better result for the Castelo Branco administration, but still bad in the contrast to the situation in the previous year: $46 \%$ of the citizens in Rio de Janeiro were dissatisfied with it and $45 \%$ were satisfied. By comparing the

\footnotetext{
${ }^{13}$ The unpopularity of Castelo Branco due to his economic policy - also among groups that had supported the coup - was observed by several authors, like Lira Neto, Castelo: a marcha para a ditadura, São Paulo, Contexto, 2004

${ }^{14}$ About the results of the economic policy, see Francisco Vidal Luna; Herbert Klein, "Transformações econômicas no período militar (1964-1985)", In: Daniel Aarão Reis Filho; Marcelo Ridenti; Rodrigo Patto Sá Motta (orgs.), A ditadura que mudou o Brasil: 50 anos do golpe de 1964, Rio de Janeiro, Zahar, 2014, p. 92-111.
} 
Table 13. Poll from the Brazilian Institute of Public Opinion and Statistics (IBOPE) conducted between February 5 and February 13, 1965, in Guanabara (505 interviewees)

\begin{tabular}{lcccc}
$\begin{array}{l}\text { Do you think the economic situation } \\
\text { of the country, during the past } \\
\text { year, improved or got worse in } \\
\text { comparison to the previous year? }\end{array}$ & Improved & $\begin{array}{c}\text { Got } \\
\text { worse }\end{array}$ & $\begin{array}{c}\text { Remained } \\
\text { the same }\end{array}$ & $\begin{array}{c}\text { Did not } \\
\text { choose an } \\
\text { answer }\end{array}$ \\
\hline
\end{tabular}

Source: Arquivo Edgard Leuenroth.

Table 14. Poll from the Brazilian Institute of Public Opinion and Statistics (IBOPE) conducted between February 5 and February 13, 1965, in Guanabara (505 interviewees) Generally, are you satisfied or dissatisfied with the administration of President Castelo Branco?

Source: Arquivo Edgard Leuenroth.

two poll results, the number of people who were dissatisfied with the Castelo Branco administration was lower than of those who realized a worse economic situation. A possible explanation is that a part of the voters who were unhappy about the economic performance might have been satisfied with other things, or maybe attributed part of the failure to the legacy of the Goulart administration.

The dissatisfaction toward the Castelo Branco administration was confirmed by the answers to another question that measured the popular support for the possible new prorogation of the general's mandate. In June 1964, as mentioned previously, $62 \%$ of the residents of Rio de Janeiro claimed to be in favor of the dictator's continuation after the end of his legal mandate. In February 1965, the opinion had drastically changed, as demonstrated by researchers of IBOPE, since $75 \%$ of the interviewees preferred a change in the country's leadership (Table 15).

\section{Final considerations}

In 1964, the political crisis was resolved by weapons or by the potential use of military force, since, despite the mobilization of troops, the expected war did not take place. ${ }^{15}$ For the decision of mobilizing the troops, the coup defenders did not need to consult the opinion of the citizens. By also considering other reasons related to skepticism, wouldn't it affect the validity of opinion polls?

Even though there are reasons to question the usefulness of the polls, I think there are more solid motives to believe in their relevance. The "opinion" was an important element for political agents and for the State - everyone considered it in search of conquering and maintaining power. The decision to implant the

${ }^{15}$ Which did not mean the absence of violence, since there were dead and tortured on the days of the coup. 
Table 15. Poll from the Brazilian Institute of Public Opinion and Statistics (IBOPE) conducted between February 5 and February 13, 1965, in Guanabara (505 interviewees) In your opinion, the election of President of the Republic must be carried out in 1966, as planned, or do you think the mandate of President Castelo Branco should be once again prolonged?

Source: Arquivo Edgard Leuenroth.

coup was influenced by the feeling that it would be supported by expressive social segments. The dictatorship was installed thanks to the military force; however, in order to succeed and gain political stability, it was necessary to acquire legitimacy. As to the reliability of IBOPE data, the analysis of surveys, especially when comparing the results from different cities and also considering other evidence of coup support, such as the large number of "marches" that were favorable to the coup and their large participants, ${ }^{16}$ reveals that the results of the polls constitute very useful elements for the historiography of dictatorship.

The data indicate the support of a little more than half of the population (from São Paulo and Rio de Janeiro) to the coup, confirming the existence of political polarization in the context of 1964 coup. Therefore, the influence of right-wing movements in the late period of the Goulart administration is clear and it convinced many people about the serious threat to order. Polls clearly show that higher social classes accepted the coup with more enthusiasm, and these were also the groups that were more sensitive to the representations about the "red danger".

However, it is essential to remember that the other half of the citizens did not support the coup or proved to be indecisive/indifferent with regard to Goulart's deposition. The available polls do not certainly show if most of the support appeared before or after the coup. The support from most people who were in favor of the coup, as shown in polls of May 1964, might have appeared not before the event but after the success of the military action, influenced by the coup or by the speeches of the winners that took over the public space.

The role of the anticommunist opinion is also worth mentioning. Data show the high concern about the presence of communist elements in the context of the Goulart administration, which was considered by most as a threat and an evil thing. It is hard to know what "communism" meant for these people; however, they certainly did not take it for the policy of fundamental reforms, which was broadly accepted - except for the right to vote for illiterate people, which could be related to the increasing potential of the left strength. It seems clear that the great fear did not involve the reforms

\footnotetext{
${ }^{16}$ About the "marches", cf. Aline Presot, "Celebrando a 'Revolução': as Marchas da Família com Deus pela Liberdade e o Golpe de 1964", In: Denise Rollemberg; Samantha Quadrat, A construção social dos regimes autoritários. Legitimidade, consenso e consentimento no século XX. Rio de Janeiro, Civilização Brasileira, 2010, p. 71-96.
} 
or the indisposition against João Goulart, who, in some polls close to the coup, appeared to have popular support. The fear was caused by the feeling of radical threats to social and political order, which was verbalized in an anticommunist language. Goulart lost legitimacy in the eyes of many when his image was associated with this "danger", which apparently stimulated most people to support the political purge. Significantly, the support to purges (prisons, cassations) was more frequent when the announced targets were the "communists".

It is important to note that the anticommunist feeling was not absurd or simple manipulation, since the left-wing groups were growing and searching to increase their influence on the Goulart administration. This analytical movement is necessary to understand the context and the choices of right-wing groups, after all, politics is a game played by at least two players. The strategies of the actors are influenced by the perception they have about the plans and the strength of their adversaries, even when distorted or exaggerated. However, the analysis that the main motivation for the coup was to fight the left-wing groups do not justify the authoritarian actions. In this line, we could get to the absurd argument that the left-wing was to blame for the coup. This argument goes against all logics. The groups that perpetrated the coup are the ones to be blamed, not their targets.

\section{There may have been support to authoritarian actions, but not necessarily the support from most of the society to implement a military dictatorship}

Besides, even if hypothetically, we could accept the point of view of those who fought against the left-wing groups, the coup was not the only option to fight for order. They could have defended their interests and ideals by using institutions and instruments that were compatible with liberal democracy. Also, defending the order did not necessary imply dictatorship, nor using torture and disappearances as a State policy. By the way, it is worth to remember the Italian and German cases of the 1970s, when the State faced the armed challenge of the extreme-left wing without a dictatorship or disappearances.

Opinion polls indicate that expressive social segments accepted the coup well and supported the purges, which shows little appreciation for institutions and civil rights. For these sectors, certainly the new regime was considered to be legitimate, or, at least, acceptable. The surveys help us understand why part of the society supported the dictatorship at first, and this explanation necessarily relates to threats to the order. However, it is important for us to remember that these strategies of legitimation were not supported by all the citizens. It is necessary to conduct further studies about the activism that was opposed to dictatorship, without accepting the mythologies of resistance, which are prone to manipulation. Likewise, it is important to look at those who were 
indifferent and the ones who adopted accommodative strategies towards the authoritarian State. ${ }^{17}$

The matter of social support to dictatorship must be studied in a temporal dimension, by observing the changes that took place throughout the years; it was 20 years of an authoritarian regime. Polls show the initial support to the coup and to purge, but also the preference for civilians in power and the desire to elect the president by direct vote. There was adherence to authoritarian measures, but not necessarily to a dictatorship led by military men. Maybe this is one of the reasons why dictatorship chose to make concessions to the liberal culture, maintaining open parliament, elections, and so on. Likewise, there would be explanation for the constant care of dictatorship leaders in denying the dictatorial character of the State, always cherishing democracy and promising its full reestablishment. Polls indicate that leaders may have acted this way because there would be little acceptance for a "pure" dictatorship, free of ambiguities.

Besides the preference for civilians in charge and direct elections, the polls show the fast erosion of the support to the Castelo Branco administration. In these conditions, in which the political opinion changed according to the conjuncture, it is difficult to talk about authoritarian consensus or consensual support to dictatorship, in terms of support from the majority. A formulation in these terms is little convincing, except if we adjust the argument to the existence of an anticommunist virtual consensus, which implied the support of the majority to authoritarian measures when the feeling of threat to order became acute.

Anyway, there is a need to look for more evidence and make further analyses. In this direction, it would be important to find polls referring to the following periods, to measure the state of the opinion at key moments, such as the protests of 1968, when the support to government decreased, or during the "economic miracle", which worked in the opposite direction, that is, increasing the feeling of legitimacy. ${ }^{18}$

Finally, the opinion regarding dictatorship and the support to it changed with time, and it does not seem like the authoritarian regime found support from most of the population throughout the whole period. After all, if there was the support from most people and the consensus of the population, why would there be the need to use constant authoritarian measures? In the balance between legitimacy and coercion, which is the base of the power in any State, both sides of the scale changed positions throughout those 20 years. The challenge is to better understand the weight of each element in the support for the long Brazilian dictatorship.

\footnotetext{
${ }^{17} \mathrm{Cf}$. Rodrigo Patto Sá Motta, As universidades e o regime militar, Rio de Janeiro, Zahar, 2014.

${ }^{18}$ For the popularity of the Médici administration, see Janaina Cordeiro, Lembrar o passado, festejar o presente: as comemorações do sesquicentenário da Independência entre consenso e consentimento. Tese de doutorado, Universidade Federal Fluminense, Niterói, 2012.
} 